DOI: $10.4274 /$ tjps. 29981

(Turkish Title: OVO, IN VITRO VE VIVO GÜNLÜKLERINNDEN FLUNARİZININ ANTİ-MIYYOGRAFIK AKTIVITESi)

\title{
Anti-Angiogenic activity of flunarizine by in ovo, in vitro and in vivo assays.
}

Chandana Kamili, Ravi Shankar Kakaraparthy, Uma Maheshwararao Vattikuti

1Cmr College Of Pharmacy, Hyderabad- 501401 (telangana), India.

2Department Of Pharmacology, Sri Sai Aditya Institute Of Pharmaceutical Sciences And Research, Surampalem. (andra Pradesh),india.

3Department Of Pharmacognosy, Trr College Of Pharmacy, Hyderabad- 500079 (telangana), India.

\section{Özet}

Giriş ve Amaç: Hücre proliferasyonunda T-tipi kalsiyum kanallarını tutulumu ve hücre göçü içindeki sodyum kanallarının rolü anjiyogenezde kapsamlı olarak incelenımiştir. Bu çalışmada, ikili bir sodyum / kalsiyum kanal blokeri olan Flunarizin; anti-anjiyojenik potansiyelini değerlendirmek için seçildi. Bu, patolojik olarak aşırı anjiyogenezin neden olduğu hastalıklarda terapötik olarak yararlı olabilir.

Metot: İyon kanalı blokörünün anti-anjiyojenik aktivitesi, civciv korioallantoik membran deneyi (ovoda), sıçan aortik halka deneyi, endotelyal hücre proliferasyon analizi, transwell migrasyon deneyi, matrigel kord benzeri morfojenez deneyi (in vitro) ve sünger implantasyonu ile tarandi. yöntem (in vivo). Test ilacının anti-anjiyogenil aktivitesi standart anti-anjiyojenik ilaç olan Bevacizumab ile karşılaştırıldı ve buna ek olarak, test yanıtları, 500mM'lik bir maksimum konsantrasyonda anjiyojenik faktör VEGE ile karşılaştırıldı.

Bulgular: Tüm gruplar kontrol grubu ile tek yönlü ANOVA kullanılarak ve post hoc testi ile karşılaştırıldı, Dunnett testi ile tüm grupların ortalamaları kontrol ortalaması ile karşılaştırıldı. Chick chorioallantoic membran testinde dallanma noktaları ve anjiyojenik skorlar değerlendirildi ve $10-5 \mathrm{M}$ ve $10-4 \mathrm{M}$ 'de anlamlı sonuçlar gözlendi. Aort halkası analizinde, filiz alanında $5-10 \mu \mathrm{M}$ azalma gözlendi ve sünger implantasyon yönteminde test edilen üç Flunarizin konsantrasyonunda sünger ağırlığında anlamlı bir azalma, kan damarlarının sayısı ve hemoglobin içeriği gözlendi. İnsan umbilikal ven endotelyal hücreleri üzerindeki çalışmalarda, test ilacı (1$100 \mathrm{nM}$ ), proliferasyonun önemli ölçüde engellenmesini, doza ve kordon benzeri tüplerin ağ uzunluğunun doza bağımlı bir şekilde azaldığını gösterdi.

Sonuçlar: Flunarizin, T-tipi kalsiyum ve sodyum kanallarını bloke ederek hücre proliferasyonu, migrasyon ve kord benzeri tüp oluşumunu inhibe ederek önemli anti-anjiyogenik etkiye sahiptir. 
Flunarizin'in bu iyon kanal modülatörünü yeniden üretmek için yapısal modifikasyonları ile ilgili daha ileri çalışmalar, kök nedeninden aşırı anjiyogenezden kaynaklanan hastalıkları tedavi edebilecektir.

Anahtar Kelimeler: Anti-anjiyogenez, civciv korioallantoik membran deneyi, sıçan aortik halka deneyi, sünger implantasyon yöntemi, insan umbilikal ven endotel hücreleri, flunarizin.

\begin{abstract}
Background and Objective: The involvement of T-type calcium channels in cell proliferation and the role of sodium channels in cell migration have been extensively studied in angiogenesis. In the present study Flunarizine, a dual sodium /calcium channel blocker; was selected to evaluate its anti-angiogenic potential. This can be therapeutically beneficial in the diseases caused due to pathologically excess angiogenesis.
\end{abstract}

Methods: The anti-angiogenic activity of ion channel blocker was screened by chick chorioallantoic membrane assay (in ovo), rat aortic ring assay,endothelial cell proliferation assay,transwell migration assay, matrigel cord-like morphogenesis assay (in vitro) and sponge implantation method (in vivo). The anti-angiogenic activity of the test drug was compared with the standard anti-angiogenic drug Bevacizumab and in addition, the test responses were compared with the angiogenic factor VEGF, at a maximal concentration of 500pM.

Results: All the groups were compared with the control group using one-way ANOVA, followed by post hoc test, the Dunnett's test to compare the mean of all the groups with the control mean.In the chick chorioallantoic membrane assay, number of branching points and angiogenic score were evaluated and significant results were observed at $10^{-5} \mathrm{M}$ and $10^{-4} \mathrm{M}$. In the aortic ring assay reduction in the area of sprouts were observed with $5-10 \mu \mathrm{M}$ and a significant reduction in weight of sponges, number of blood vessels formed and hemoglobin content were observed at all the three tested concentrations of Flunarizine in the sponge implantation method. In the studies on human umbilical vein endothelial cellsthe test drug (1-100nM) showed significant inhibition of proliferation, migration and decrease in network length of cord like tubes in a dose dependent manner.

Conclusions: Flunarizine has significant anti-angiogenic action byinhibiting the cell proliferation, migration and cord like tube formation, which have resulted by blocking the T-type 
calcium and sodium channels. Further studies on the structural modifications of Flunarizinefor repurposing this ion channel modulator will be able to treat the diseases due to excess angiogenesis from the root cause.

Key Words: Anti-angiogenesis, chick chorioallantoic membrane assay, rat aortic ring assay, sponge implantation method, human umbilical vein endothelial cells, flunarizine.

\section{Introduction}

The term angiogenesis or neovascularization means the formation of new blood vessels from existing vasculature. Blood capillaries supply oxygen: more capillaries can increase tissue oxygen conduction and hence improve energy production; fewer capillaries results in ischemia, hypoxia and even anoxia in the tissues[1].Thus, angiogenesis is important for both normal physiology and in pathological conditions [24].

Endothelial cell (EC) structure and functional integrity is important in the maintenance of the vessel wall and circulatory functions, and most of these endothelial functions are regulated by ion channels[5,6].Role of ion channels in pathophysiology of diseases has been extensively discussed[7-9]. Despite their prime role in several diseases, there are hardly few drugs targeting specifically the ion channels as therapeutics Inhibitors for the treatment of diseases caused due to excessive angiogenesis. Such clinically approved ion channel modulators with well known safety profiles may be reframed in the treatment of many disease saving significant time and money.

In the present study,Flunarizine (FLN), a dual $\mathrm{Na}^{+} / \mathrm{Ca}^{2+}$ channel blocker was selected to screen its anti-angiogenic potential. FLN, diphenylpiperazine analog acts on both $\mathrm{Na}^{+}$and $\mathrm{Ca}^{2+}$ channels [20]. The test drug is a T-type calcium channel blocker which has been studied as extensively unregulated in most of the tumor types. The anti-angiogenicpotential of the test drug FLN was tested at three different doses in different methods by an in ovo method, chorioallantoic membrane(CAM) assay; an in vitro 
method, rat aortic ring assay,endothelial cell proliferation assay,transwell migration assay, matrigel cordlike morphogenesis assay; andin vivo method, sponge implantation assay.

\section{Material and Methods}

\subsection{Chemicals}

Flunarizine, ketamine, xylazine and tramadol werepurchased from N.R. CHEM, India. Matrigel was purchased from Becton Dickinson India Pvt.Ltd, Gurgaon India. Gel foam and Dulbecco's modified Eagle's medium were supplied by life technologies (India) Pvt.Ltd. Well plates were purchased from Hi media laboratories Pvt. Ltd, India. Bevacizumab, VEGF, penicillin, streptomycin, amphotericin, gentamycin, heparin, bovine serum albumin, gelatinand M199 were obtained from Sigma-Aldrich (India). All the chemical and reagents used in the study are of AR grade.

\subsection{Equipment}

All the equipment of CMR College of pharmacy was used. BOD incubator, Dona analytical balance, Digital $\mathrm{P}^{\mathrm{H}}$ meter, Ever Shine 697 homogenizer, laminar airflow unit, labomed trinocular microscope were purchased from MH enterprises, Hyderabad, India.

\subsection{Experimental Animals}

Fourty two healthy male Wistar Albino rats weighing in between 150-200 g were selected for in vivo methods and for in vitro assay. Animals were obtained from Teena Labs Pvt Ltd, Hyderabad, Telangana state, India. Fertilized leghorn chicken eggs were selected for in ovo assay. All the procedures were performed according to the CPCSEA under a protocol approved by the Institutional Animal Ethics Committee (IAEC) with project license numbers (CPCSEA /1657/ IAEC/CMRCP/PhD-15/42)

\subsection{Chick Chorioallantoic Membrane Assay}

This is an in ovo angiogenesis assay for identification and quantification of antiangiogenic agents. Eggs were collected from the hatchery at day 0 ' and checked for any damage. They were randomly grouped into control, VEGF, Bevacizumab and three test concentrations,each containing six eggs. Eggs were disinfected using ethanol then incubated under condition of constant humidity and at a constant temperature of $37^{\circ} \mathrm{C}$. On the $3^{\text {rd }}$ day, a hole was drilled at the narrow end and 2-3 $\mathrm{ml}$ of albumin was withdrawn with 18 gauge hypodermic needle. The hole was sealed with sterile tape and put back for 
incubation. On the $7^{\text {th }}$ day, a window was opened on the shell, sterile gel foam or sponge $(3 \mathrm{~mm} \times 3 \mathrm{~mm} \times 1 \mathrm{~mm})$ piece was placed on top of the membrane. The control group was given saline; the test and standard groups were impregnated with their respective doses. Eggs were incubated till day 14. On the $14^{\text {th }}$ day,CAM tissues directly beneath sponge were removed from control and treated CAM samples. Tissues were placed in $10 \%$ formalin, stained with hematoxylin-eosin, and then examined under trinocular microscope. The vessel branching points in the square area were counted and analyzed for each treatment group. The resulting angiogenesis index is the mean \pm SEM of new branch point in each set of samples. 'Angiogenesis score 1-4 was given to each egg based on number of branching points. If number of branching points is $\geq 35$, the angiogenesis score is 4 . If branches are between $25-34$, score is 3 and for $15-24$, the score is 2 . If the points are $<15$, the score is $1^{\prime}$. The concentrations $\left(10^{-6} \mathrm{M}, 10^{-5} \mathrm{M}, 10^{-4} \mathrm{M}\right)$ were selected based on the results of the previous studies. In the previous study the concentration of $10^{-5} \mathrm{M}$ has shown sub maximal efficacy of the drug. The classical molarity formula $M=\mathrm{m} / \mathrm{V}$ was used to find out the required drug amount to provide $10^{-4} \mathrm{M}$ concentration. First the concentration of $10^{-4} \mathrm{M}$ was prepared, and then the other concentrations were prepared from the earlier by serial dilutions[10-13].

\subsection{Rat Aortic Ring Assay}

This method is a widely used in vitro assay for the evaluation of both angiogenic and antiangiogenic compounds. One healthy male Wistar Albino rat for each group was selected. It was sacrificed by cervical dislocation, thoracic cavity was cut opened and the visceral organs were separated. Thoracic aorta was identified and isolated by cutting both the ends. Immediately it was transferred to cold phosphate buffer solution (PBS) supplied with aeration. Fibro-adipose tissue was isolated, the proximal and distal $2 \mathrm{~mm}$ segments of aorta were cut away. Aorta were cut into $1 \mathrm{~mm}$ ring sections and washed with PBS. These rings were placed in the 24 well plates with $150 \mu 1$ of matrigel. Rings were overloaded with matrigel and were left to polymerize for $1-2$ hours at $37^{\circ} \mathrm{C}$. Then they were exposed to hypoxia for 2 hours. This hypoxic condition stimulates formation of sprouts. The rings were reoxygenated and then incubated for seven days. Area of sprouts was quantified by the measurement of length and abundance of microvessel-like extension from the explants[14-16].

\subsection{Sponge Implantation Method}


In the sponge implantation method, the surgical procedure was done by a single investigator to increase the reproducibility of the process. Sponges were implanted subcutaneously(s.c). All the surgical instruments used in study were sterilized by autoclaving at $121^{\circ} \mathrm{C}$ for $25 \mathrm{~min}$. The sponges of $2 \mathrm{~cm}$ diameter and $8 \mathrm{~mm}$ thickness were prepared and sterilized by soaking in $70 \%$ ethanol for three hours and then boiling at $70^{\circ} \mathrm{C}$ for half-an-hour. This in vivo method was carried out by anaesthetizing the rats by a cocktail of Ketamine $(80 \mathrm{mg} / \mathrm{kg}$ ) and Xylazine $(5 \mathrm{mg} / \mathrm{kg})$. Then the skin was cut open by surgical blade. Sterile sponge was implanted subcutaneously by creating an air pocket which was sutured back by $5 / 0$ silk sutures. Two such sterile sponges were implanted on the mid-dorsal line of the body. When the animal recovered from anesthesia, they were allowed to have normal diet and water. The animals after the surgery were caged individually. Tramadol at a dose of $0.9 \mathrm{mg} / \mathrm{kg}$ was injected intramuscularly (i.m)twice a day in the morning and evening, Gentamycin at a dose of $2 \mathrm{mg} / \mathrm{kg}$ was injected i.m in the morning. The analgesic and antibiotic drugs were given for the three days post-operatively. Standard and test drugs were given to the sponges of their respective groups for 13 days after the implantation. On the $14^{\text {th }}$ day animals were sacrificed and the sponges were dissected out. Sponges were weighed, amount of hemoglobin and number of vessels per sponge were quantified. The drug concentrations were expressed as $\mathrm{mg} / \mathrm{kg}$. The therapeutic human range of each drug in the subcutaneous route was obtained from the literature and three animal doses were calculated by the formula

$$
\text { Surface area of animal }
$$

Dose of the animal $=\ldots \ldots \ldots \ldots \ldots \ldots \ldots \ldots \ldots \ldots \ldots$ Human dose

$$
\text { Surface area of Human }
$$

Where,

Rat surface area $=0.025 \mathrm{sq} . \mathrm{m}$

Human surface area $=1.6 \mathrm{sq} . \mathrm{m}$

First the highest concentration of each drug was prepared, and then the other concentrations were prepared from the earlier by serial dilutions[17-19].

Procedure for determining hemoglobin content: The sponges after removal from rats were soaked in double distilled water and homogenized completely over ice platform for $5 \mathrm{~min}$. The homogenate was centrifuged at 10,000 rpm in cooling centrifuge for $5 \mathrm{~min}$ and the supernatant liquid obtained was used to estimate hemoglobin content (g/Dl). 
Procedure for determining number of blood vessels formed per sponge: The sponges were bisected, fixed in saline at $4^{\circ} \mathrm{C}$ for $1 \mathrm{~h}$. The sponges were immersed in $75 \%$ ethanol for thirty min, finally kept in $10 \%$ formalin and paraffin sections $(10 \mathrm{pm})$ were prepared, stained with hematoxylin-eosin. The prepared slides were then observed under trinocular microscope. The circular spaces amidst the fibroblast regions present were counted as they represent vessels formed in the sponges.

\subsection{Endothelial Cell Culture}

Human umbilical vein endothelial cells (HUVECs) were grown on gelatinized dishes in M199 supplemented with $15 \%$ fetal calf serum, $50 \mathrm{U} / \mathrm{ml}$ penicillin, $50 \mathrm{mg} / \mathrm{ml}$ streptomycin, $50 \mathrm{mg} / \mathrm{ml}$ gentamycin, $2.5 \mathrm{mg} / \mathrm{ml}$ amphotericin $\mathrm{B}, 5 \mathrm{U} / \mathrm{ml}$ heparin, and $150-200 \mathrm{mg} / \mathrm{ml}$ endothelial cell growth supplement. Cells were used between passages 1 and 3. Each experiment shown derives from three independent repeats, each time using different pools (isolates) and/or passages of cells [24].

\subsection{Endothelial Cell Proliferation Assay}

The HUVECs were seeded in 24-well plates at a density of $6,000 \mathrm{cells} / \mathrm{cm}^{2}$ and incubated overnight in Dulbecco's modified Eagle's medium. Cells were exposed to different concentrations of FLN, Bevacizumab, VEGF or vehicle and allowed to proliferate for 48 hours. At the end of this incubation time, the cells were trypsinized, and their number was determined using a Neubauer hemocytometer [25].

\subsection{Transwell Migration Assay}

The capacity of endothelial cells to migrate through a pore-bearing membrane was assessed using $6.5 \mathrm{~mm}$ diameter transwell chambers with polycarbonate membrane inserts $(8 \mathrm{~mm}$ pore size). Control or endothelial cells were serum starved overnight. Cells were trypsinized, and $1 * 10^{5}$ cells were added to each transwell in $100 \mathrm{ml}$ of serum-free medium containing $0.2 \%$ bovine serum albumin in the control and in the presenceof different concentrations of FLN (1nM,10nM,100nM), Bevacizumab and VEGF. Cells 
were allowed to migrate for 4 hours, after which the non-migrated cells at the top of the transwell filter were removed with a cotton swab. The migrated cells on the bottom side of the filter were fixed in Carson's solution for 30 minutes at room temperature and then were stained with toluidine blue. Migrated cells were scored and averaged from eight random fields per transwell as previously described elsewhere $[26]$.

\subsection{Matrigel Cord-Like Morphogenesis Assay}

The formation of cord-like structures by endothelial cells (HUVECs) was assessed in growth factorreduced matrigel. The cell groups were plated in 96-well plates pre-coated with $45 \mathrm{ml}$ of matrigel per well. After 8 hours of incubation, cord-like structure formation was quantified. One image per well was analyzed and used for the statistical analysis [25,27].

\subsection{Statistical analysis}

The statistical analysis was carried out by using Graph Pad Prism 5. Results were presented as mean \pm SEM. The differences between the groups were compared by one way ANOVA followed by post hoc Dunnett's test. In the statistical analysis all the groups were compared with the control group. Results were considered statistically significant at $\mathrm{p}$ value $<0.05$.In all the groups of CAM assay, rat aortic ring assay and sponge implantation method, $\mathrm{n}=6$. (Fig. $2 \& 3$ )

\section{Results}

In the chick chorioallantoic membrane assay (in ovo), the dual ion channel blocker exhibited marked antiangiogenic activity at all the tested concentrations, In rat aortic ring assay (in vitro), reduction in the area of sprouts were observed. A noticeable reduction in weight of sponges and inhibition in the growth of new blood vessels; and a very sharp reduction in hemoglobin content were observed, which was better than the standard drug response (in vivo).

\subsection{Results of Chick Chorioallantoic Membrane (CAM) Assay}


In the Assay,on the $14^{\text {th }}$ day the CAM tissues directly beneath the sponge were removed from control and treated CAM samples. The vessel branching points in the square area equal to the region of each sponge were counted(Fig .1). Angiogenesis score 1-4 was given to each egg based on number of branching points. Effect of the drug treatment on the two evaluation parameters that is, number of branching points and angiogenic score are represented in the Fig.2A \& 2B. The results of three doses of FLN, the standard anti-angiogenic drug Bevacizumab and VEGF were statistically compared with the control results. Significant results were observed with all the three test dose selected; $10^{-6} \mathrm{M}, 10^{-5} \mathrm{M}$ and $10^{-4} \mathrm{M}$

\subsection{Results of Rat Aortic Ring Assay}

Photographs showing the abundance of microvessel-like extensions from the explants are represented in the Fig.1. Significant reduction in the area of sprouts was observed with $5 \mu \mathrm{M}$ and $10 \mu \mathrm{M}$ of the drug. (Fig.2C)

\subsection{Results of Sponge Implantation Method}

In the sponge implantation method, the evaluation parameters are weight of the sponge, number of vessels per sponge, haemoglobin content and the histopathology of the sponge. A moderate reduction in weight of sponges and a prompt inhibition in the growth of new blood vessels and hemoglobin content were observed at $1.0 \mathrm{mg} / \mathrm{kg}$ and $10 \mathrm{mg} / \mathrm{kg}$ of the drug (Fig,2D,2E and 2F). The sections of the sponges were observed under trinocular microscope. The circular spaces amidst the fibroblast regions were counted as they represent new vessels formed in the sponges. In the VEGF group large numbers of vessels wereidentified, in the standard very less microvessels were formed due to strong anti-angiogenic action and the test drug showed a dose dependent decrease in the number of blood vessels per sponge (Fig.1). 


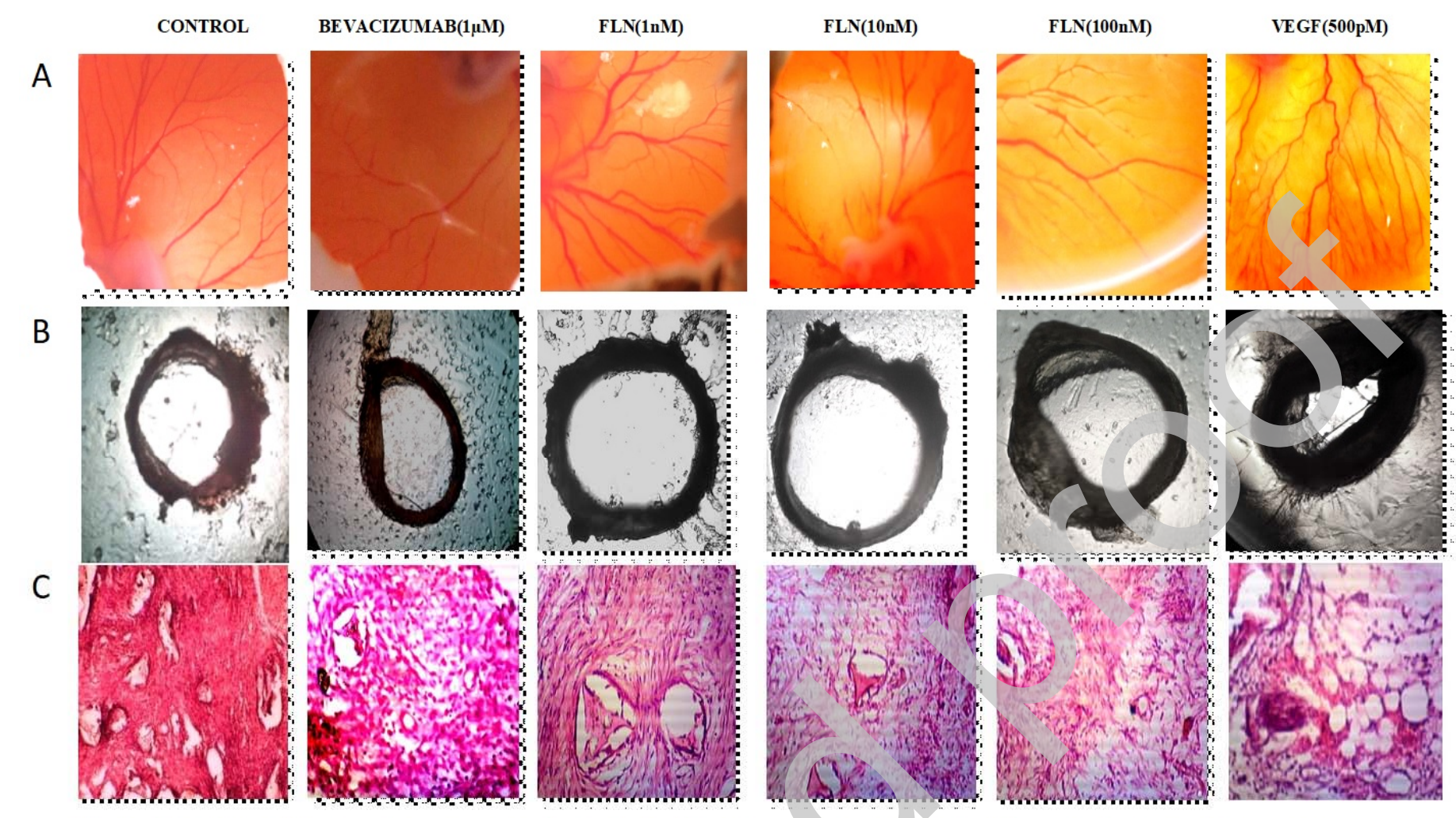

Fig. (1): FLN inhibited angiogen esis in ovo, in vitro and in vivo. (A)In the CAM assay number of branching points from each major vessel were counted. (B) Photographs of explants in the aortic ring assay shows the micro vessel like extensions. (C) The histological sections of the sponges show circular spaces amidst the fibroblast region represent the newly formed blood vessels.

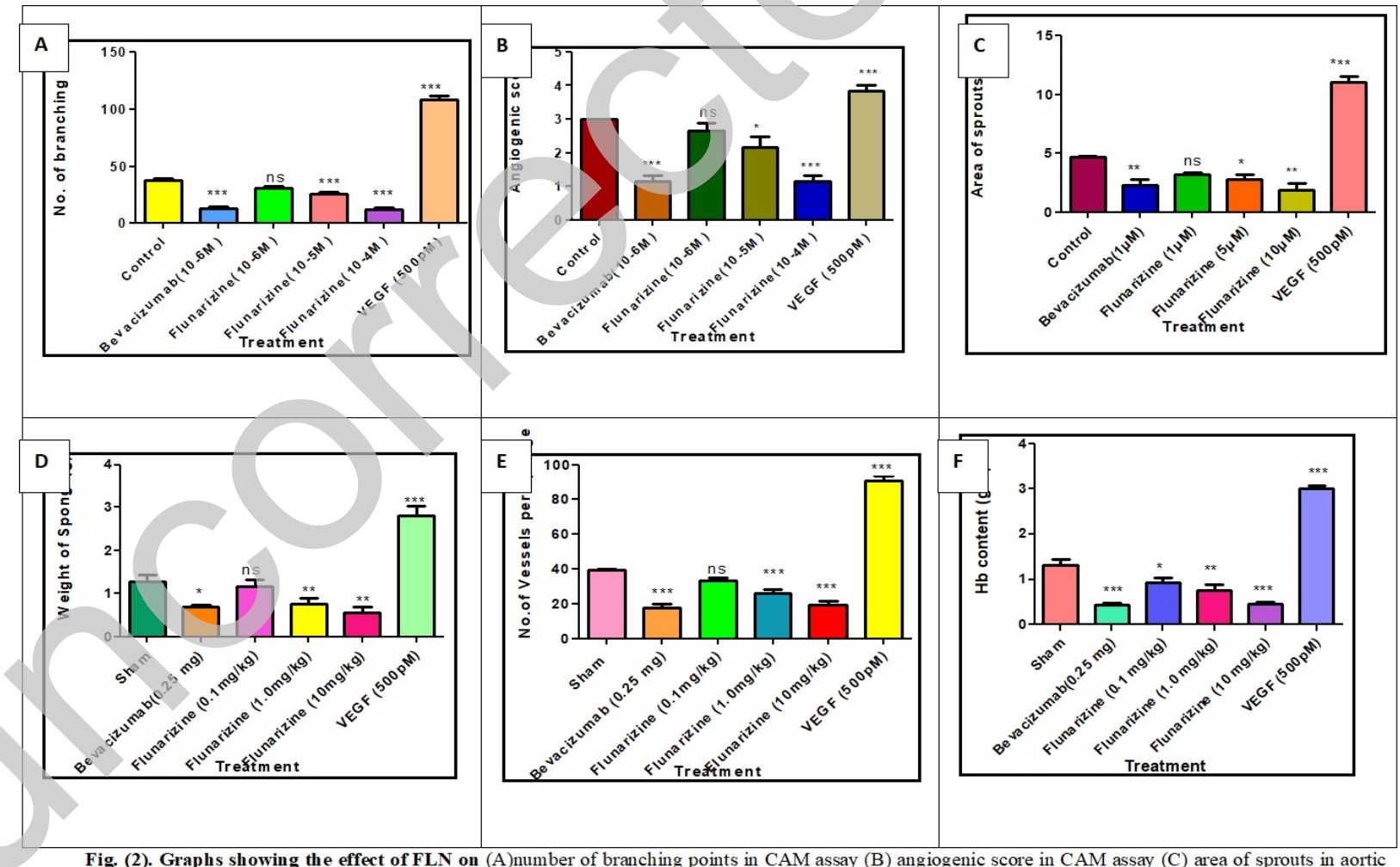

Fig. (2). Graphs showing the effect of FLN on (A)number of branching points in CAM assay (B) angiogenic score in CAM assay (C) area of sprouts in aortic ring assay (D) weight of sponge in sponge implantation method (E) number of vessels per sponge (F) Hemoglobin content per sponge in sponge implantation method. All the results were expressed as Mean $\pm \mathrm{SEM} ; \mathrm{n}=6 .{ }^{* * *} \mathrm{p}<0.001, * * \mathrm{p}<0.01,{ }^{*} \mathrm{p}<0.05$ Vs Control, ns-Non significance. 


\subsection{Results of Endothelial Cell Proliferation Assay, Transwell Matrigel and Cord-Like}

\section{Morphogenesis Assay}

$\mathrm{Na}^{+}$and $\mathrm{Ca}^{2+}$ channels are important for cell proliferation, migration and cord like network formation. To further test the link between channel inhibition and anti-angiogenesis, endothelial cell based assays triggering proliferation and mobilization were performed.In the cell proliferation assay VEGF resulted in elevated proliferation (increase of $49 \%$ ), whereas bevacizumab and the three doses of FLN showed significant inhibition of proliferation respectively (inhibition by $50 \%, 79.3 \%, 69.7 \%, 58.3 \%$ ). In addition, test doses of FLN inhibited cell motility through transwell compartments comparable to vehicle control, respectively. To further assess the anti-angiogenic property of the test drug, cord like tube formation assay was performed. Significant inhibition was observed with the test doses $(69.3 \%, 59.7 \%, 48.3 \%$ respectively).(Fig.3\& 4)



3). Modulation of endothelial cell respon ses to FLN, Bevacizumab and VEGF . (A)Cell proliferation was determined by cell counting with a hemocytometer Representative images of tube formation after being treated with FLN for 2 h following VEGF stimulation (C). Quantitative data of scratch wound-healing ition in HUVECs treated with FLN for $24 \mathrm{~h}$ under VEGF stimulation. Cord-like network morphogenesis in vitro is affected by $\mathrm{K}_{\text {ATP }}$ modulation 


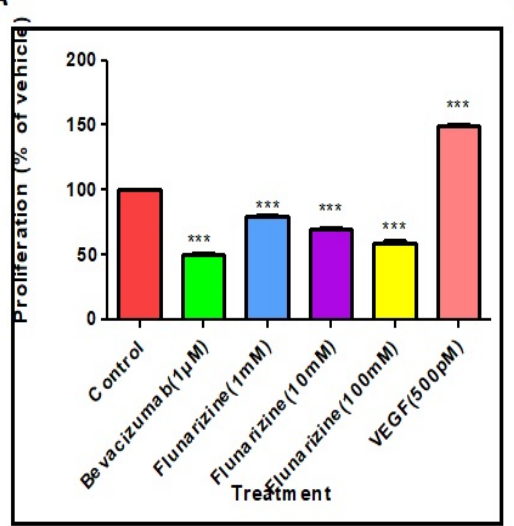

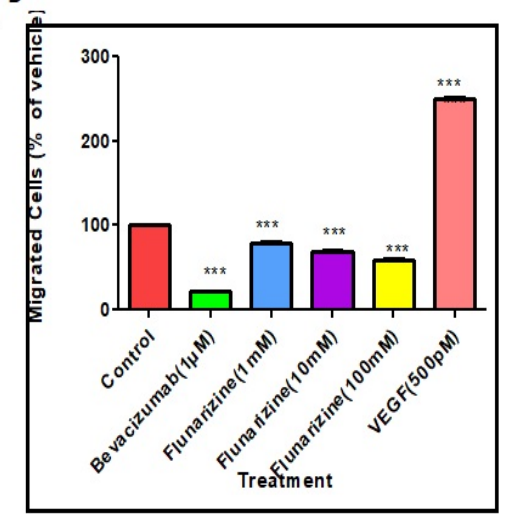

C

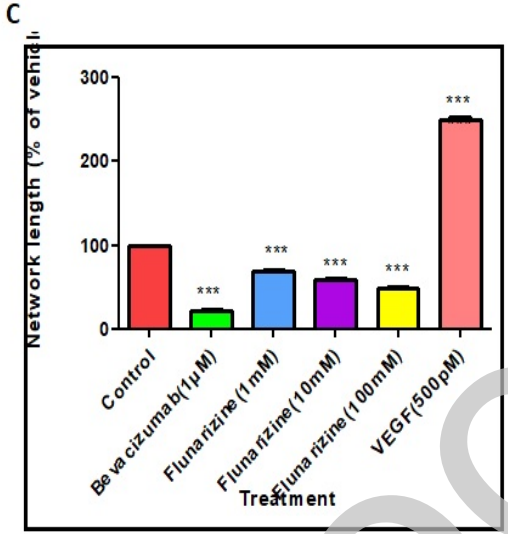

Fig. (4). Graphs showing the effect of FLN on (A)Proliferation assay (B) Migrated cells (C) Network length. All the results were expressed as Mean \pm SEM; $\mathrm{n}=6 .{ }^{* * * \mathrm{p}}<0.001, * * \mathrm{p}<0.01,{ }^{*} \mathrm{p}<0.05$ Vs Control, ns-Non significance.

\section{Discussion}

FLN is a dual sodium /calcium blocker [20].It acts on sodium and $\mathrm{Ca}^{2+}$ channels, blocks influx of $\mathrm{Ca}^{2+}$ ions. $\mathrm{Ca}^{2+}$ ions have long been known as secondary messengers in various cellular signaling resulting in angiogenesis. The fact that deprivation of extracellular $\mathrm{Ca}^{2+}$ leads to cell growth arrest in $\mathrm{G} 1 / \mathrm{S}$ indicates that $\mathrm{Ca}^{2+}$ is required for cell cycle progression $[21,22,23]$.

One of $\mathrm{Ca}^{2+}$ regulation mechanisms is binding of calcium to calmodulin protein. Intracellular $\mathrm{Ca}^{2+}$ binds with calmodulin (CaM) II, in turn activates calcium-calmodulin-dependent protein kinases and regulates pro-survival transcriptional proteins.

In the chick chorioallantoic membrane assay, the ion channel blocker exhibited potent antiangiogenic activity at the all the three test concentrations of $10^{-6} \mathrm{M}, 10^{-5} \mathrm{M}$ and $10^{-4} \mathrm{M}$. Reduction in the area of sprouts in rat aortic ring assay was observed with $5 \mu \mathrm{M}$ and $10 \mu \mathrm{M}$ of FLN. A significant reduction in weight of sponges, number of blood vessels formed and hemoglobin content were observed at $1 \mathrm{mg} / \mathrm{kg}$ and $10 \mathrm{mg} / \mathrm{kg}$. The results revealed that FLN has significant inhibition of sprout formation and branching in the dose dependent manner. Modulation of endothelial cell response to FLN was significant at all the test doses of $1 \mathrm{nM}, 10 \mathrm{nM}$ and $100 \mathrm{nM}$ on the endothelial cell proliferation, migration and tube formation assays. FLN being a strong blocker of $\mathrm{Ca}^{2+}$ ions influx gave significant anti angiogenic results. This drug serves as good chemical templet, which can be structurally modified for more site specific actions for the anti angiogenic therapy.

\section{Conclusion}


The anti-angiogenic property of ion channel modulator, FLN was thoroughly evaluated by in ovo, in vitro and by in vivostudies. The test drug showed very potent anti-angiogenic activity, even better than the standard drug bevacizumab at a concentration range of 5-10 $\mu \mathrm{M}$.The very strong anti- angiogenic potential is due to effective blockage of $\mathrm{Ca}^{2+}$ influx. $\mathrm{Na}^{+} / \mathrm{Ca}^{2+}$ dual blocker inhibits the $\mathrm{Ca}^{2+}$ influx with double the strength. Calcium dynamics play a crucial role in the critical steps of angiogenesis like cell migration, proliferation and even in cell death. Molecular modifications of the ion channel modulator used in the present study will evolve endothelial cell targeted chemical moieties. Furthermore, such endothelial targeted chemical moieties can be formulated suitably to achieve a site specific action which minimizes the side effects.

\section{Acknowledgements}

We thank the management of CMR College of pharmacy to support us to perform the research in the institution.

\section{Conflicts of Interest}

No conflict of interest was declared by the authors.

\section{Funding Agency}

The research was partially supported by University grants commission, minor research project grant.(Proposal Number: 3228; ROMRP-SERO-PHAR-2015-16-68663)

\section{References}

1. Adair TH, Montani JP. Angiogenesis. in colloquium series on integrated systems physiology: From molecule to function. Morgan \& Claypool Life Sciences. 2010

2. Tahergorabi Z, Khazaei M. A review on angiogenesis and its assays. Iranian journal of basic medical sciences. 2012 Nov;15(6):1110.

3. Folkman J. Angiogenesis in psoriasis: therapeutic implications. Journal of Investigative Dermatology. 1972 Jul 1;59(1):40-3.

Khurana R, Simons M, Martin JF, Zachary IC. Role of angiogenesis in cardiovascular disease. Circulation. 2005 Sep 20; 112(12):1813-24.

5. Galley HF, Webster NR. Physiology of the endothelium. British journal of anaesthesia. 2004 
Jul 1; 93(1):105-13.

6. Karamysheva AF. Mechanisms of Angiogenesis. Biochemistry (Moscow). 2008 Jul; 73(7):751-62.

7. Munaron L. Systems biology of ion channels and transporters in tumor angiogenesis: An omics view. Biochimica et Biophysica Acta (BBA)-Biomembranes. 2015 Oct 31; 1848(10):2647-56.

8. Nilius B, Droogmans G. Ion channels and their functional role in vascular endothelium. Physiological reviews. 2001 Jan 10; 81(4):1415-59.

9. Arcangeli A, Becchetti A. New trends in cancer therapy: targeting ion channels and transporters. Pharmaceuticals. 2010 Apr 20; 3(4):1202-24.

10. Lokman NA, Elder AS, Ricciardelli C, Oehler MK. Chick chorioallantoic membrane (CAM) assay as an in vivo model to study the effect of newly identified molecules on ovarian cancer invasion and metastasis. International journal of molecular sciences. 2012 Aug 10; 13(8):9959-70.

11. Peifer C, Dannhardt G. A novel quantitative chick embryo assay as an angiogenesis model using digital image analysis. Anticancer research. 2004 May 1;24(3A):1545-52.

12. Cruz A, Parnot C, Ribatti D, Corvol P, Gasc JM. Endothelin-1, a regulator of angiogenesis in the chick chorioallantoic membrane. Journal of vascular research. 2001 Dec 7; 38(6):536-45.

13. Caglar Yildiz, Ali Cetin, Fatih Demirci, Zubeyde Akin Polat, Tuba Kiyan, Ahmet Altun, Meral Cetin, Ozlem Kayim Yildiz, Ismihan Goze. Anti-Angiogenic Effects of Diltiazem, Imatinib, andBevacizumab in the CAM Assay. International Journal of Scientific and Research Publications. 2013 August;3(8).

14. AlMalki WH, Shahid I, Mehdi AY, Hafeez MH. Assessment methods for angiogenesis and current approaches for its quantification. Indian journal of pharmacology. 2014 May; 46(3):251.

15. Goodwin AM. In vitro assays of angiogenesis for assessment of angiogenic and anti-angiogenic agents. Microvascular research. 2007 Nov 30; 74(2):172-83.

Khoo CP, Micklem K, Watt SM. A Comparision of Methods for Quantifying Angiogenesis in the Matrigel Assay in vitro. J Tissue Eng. 2011, 17(9): 895-906. 
17. Veeramani VP, Veni G. An essential review on current techniques used in angiogenesis assays. International Journal of PharmTech Research. 2010 Feb; 2(4):2379-87.

18. Lokman NA, Elder AS, Ricciardelli C, Oehler MK. Chick chorioallantoic membrane (CAM) assay as an in vivo model to study the effect of newly identified molecules on ovarian cancer invasion and metastasis. International journal of molecular sciences. 2012 Aug 10; 13(8):9959-70.

19. Lee MS, Moon EJ, Lee SW, Kim MS, Kim KW, Kim YJ. Angiogenic activity of pyruvic acid in in vivo and in vitro angiogenesis models. Cancer research. 2001 Apr 15; 61(8):3290-3.

20. Joann J. Geer, David J.Dooley, Michael E. Adams. $\mathrm{K}^{+}$-stimulated $\mathrm{Ca}^{+}$flux into rat neocortical mini-slices is blocked by $\omega$-Aga-IVA and the dual $\mathrm{Na}^{+} / \mathrm{Ca}^{+}$channel blockers lidoflazine and FLN. Neuroscience letters, 1993, 158:97-100.

21. Jean-Yves LG, Halima OA, Olivier S, Pierre B, Ahmed A, Christophe V. Voltage-gated ion channels, new targets in anti-cancer research. Recent patents on anti-cancer drug discovery. 2007 Nov 1; 2(3):189-202.

22. El $\square$ Kenawi AE, El $\square$ Remessy AB. Angiogenesis inhibitors in cancer therapy: mechanistic perspective on classification and treatment rationales. British journal of pharmacology. 2013 Oct 1;170(4):712-29.

23. Urrego D, Tomczak AP, Zahed F, Stühmer W, Pardo LA. Potassium channels in cell cycle and cell proliferation. Phil. Trans. R. Soc. B. 2014 Mar 19; 369(1638):20130094.

24. Su M, Huang J, Liu S, Xiao Y, Qin X, Liu J, Pi C, Luo T, Li J, Chen X, Luo Z. The antiangiogenic effect and novel mechanisms of action of Combretastatin A-4. Scientific reports. 2016 Jun 24;6:28139.

25. Pyriochou A, Tsigkos S, Vassilakopoulos T, Cottin T, Zhou Z, Gourzoulidou E, Roussos C, Waldmann H, Giannis A, Papapetropoulos A. Anti $\square$ angiogenic properties of a sulindac analogue. British journal of pharmacology. 2007 Dec 1;152(8):1207-14.

26. Umaru B, Pyriochou A, Kotsikoris V, Papapetropoulos A, Topouzis S. ATP-Sensitive Potassium Channel Activation Induces Angiogenesis. 
27. Papapetropoulos A, Pyriochou A, Altaany Z, Yang G, Marazioti A, Zhou Z, Jeschke MG, Branski LK, Herndon DN, Wang R, Szabó C. Hydrogen sulfide is an endogenous stimulator of angiogenesis. Proceedings of the National Academy of Sciences. 2009 Dec 22;106(51):21972-7. 